Vol.45, n. 4 : pp. 451-455, December 2002

ISSN 1516-8913 Printed in Brazil

\title{
Experimental bovine infection with Taenia saginata eggs: recovery rates and cysticerci location
}

\author{
João Carlos Minozzo ${ }^{1}$, Rubens L. Ferreira Gusso ${ }^{1}$, Edilene A. de Castro ${ }^{2}$, Oscar Lago ${ }^{3}$ and \\ Vanete Thomaz Soccol ${ }^{2 *}$ \\ ${ }^{1}$ CPPI - Centro de Produção e Pesquisas de Imunobiológicos; Secretaria de Estado da Saúde do Paraná; \\ Piraquara - PR - Brazil. ${ }^{2}$ UFPR - Universidade Federal do Paraná; Departamento de Patologia Básica; Centro \\ Politécnico; Jardim das Américas; 81531-990; Curitiba - PR - Brazil. ${ }^{3}$ LACEN - Laboratório Central do Estado do \\ Paraná; Curitiba - PR - Brazil
}

\begin{abstract}
Studies were carried out on the recovery rate and cysticerci location in bovines experimentally infected with Taenia saginata eggs. Three calves of 6.5 months and one with 19 months of age were infected orally with $2 \times 10^{4}$ eggs of Taenia saginata. A fifth calf served as control. After 90 days of infection, the animals were slaughtered and organs and skeletal muscles were inspected using a slicing technique every $5 \mathrm{~mm}$. From the four infected calves, 702 cysticerci were recovered, of which 570 (81.2\%) were alive and 132 (18.8\%) were degenerated. The recovery rate ranged from 0.01 to $1.43 \%$ with an average of $0.88 \%$. The cysticerci presented the following anatomical distribution: hioideos muscles 02 (0.28\%), kidneys 03 (0.43\%), tongue 07 (1.00\%), liver 12 (1.71\%), lungs 15 (2.14\%), diaphragm 18 (2.56\%), mastication muscles 25 (3.56\%), heart 49 (6.98\%), anterior muscle 323 (46.00\%) and posterior muscle $248(35.33 \%)$.
\end{abstract}

Key words: Taenia saginata, Cysticercus bovis, Cysticerci location

\section{INTRODUCTION}

Cysticercosis is an infection caused by cysticercus, larval stage of Cestoda Family Taeniidae. These parasites have their evolution in two different hosts, the ultimate one are the humans and the intermediary are generally household animals. The World Health Organization (WHO, 1983) has classified the prevalence of Taenia saginata in three different groups: highly endemic countries or regions with their presence in human population above $10 \%$; moderate prevalence with infection rate between 0.1 and $10 \%$; low prevalence with infection rate below $0.1 \%$ or the total absence of the endemic organism. According to WHO classification, South American countries are included among the moderate prevalence of Taenia saginata.

In Brazil there are no conclusive data about the prevalence of Taenia infection and cysticercosis in bovines. Santos (1993) found that $5.1 \%$ of slaughtered bovines in federally inspected slaughterhouses showed cysticercosis infection.

The incidence of Taenia infection and cysticercosis in humans and animals is high in some regions of the State of Paraná. Routine fecal examination survey, realized in the state between 1990 and 1993 , showed that $0.54 \% 539,741$ tests

* Author for correspondence 
were positive for the presence of Taenia sp. eggs. The Federal Inspection Service DIPOA/SDA/MAARA determined $3.06 \%$ of 2,781,634 bovines slaughtered between 1989 and 1991 presented cystercercosis (I Encontro do Cone Sul e Seminário Latino Americano sobre Teníase e Cisticercose, Curitiba - Paraná, mar. 1994). The main goal of this work was to evaluate the number, location, recovery rate and biological stage of cysticerci in bovines experimentally infected with Taenia saginata eggs.

\section{MATERIAL AND METHODS}

Eggs. Gravid proglottids of Taenia saginata were obtained from non-treated patients in laboratories from the Curitiba municipality. Around 20 gravid segments were identified as Taenia saginata by compression between two glass plates and the microscopic analysis of uterine ramifications (15 to 30 ramifications). The identified segments were opened with a stiletto and their eggs were put into a $0.85 \% \mathrm{NaCl}$ solution. The egg number was estimated with a Neubauer chamber. Aliquots of 2 x $10^{4}$ eggs were placed in test tubes with $40 \mathrm{ml}$ of saline solution.

Animals. The calves belonged to Hosltein Race and they were bought in the Curitiba area. The animals were raised in Centro de Produção e Pesquisas de Imunobiológicos (CPPI). Initially they were fed with powdered milk, later they were fed with alfalfa hay and pellets ration, leguminous plants were much later introduced as feeding supplements for the animals.

Infection. Four calves were infected with Taenia saginata eggs and one non-infected calf was used as control. At the infection time three calves were 6.5 months old and one was 19 months old. Each animal received by oral route $2 \times 10^{4} \mathrm{~T}$. saginata eggs. Then, following the inoculation, they were kept for 120 hours in individual stalls. During this time, their feces were collected and kept until the fermentation and decomposition of the organic matter.

Slaughter of animals. Control and infected animals were slaughtered in a federal inspected slaughterhouse in the same conditions other animals were slaughtered. The slaughtering took place 90, 104 and 111 days after the infection. A routine inspection was carried out in the slaughterhouse. The carcass and the organs, except the intestinal viscera, were removed to CPPI where a careful inspection took place using the slicing technique.

Muscular and organ necropsy. All organs and animal muscles were carefully sliced each $5 \mathrm{~mm}$ as it was described by Fan et al., (1989, 1992); Hayunga et al., (1991); Kyvsgaard et al., (1991); Smith et al., (1991).

Classification and identification of recovered cysticerci. The recovered cysticerci were classified as alive or degenerated during the necropsy. The alive ones were considered immature when they presented a white discoloration without distinction of proto scolex, smooth shape and failed when any tentative of evagination was performed. They were considered mature when proto scolex was present and it was possible to perform the evagination. The degenerated cysticerci were of two types: a cheesy one, when its contents were yellowish and smooth or a calcified one, when its contents were solid and perceptible when they were sliced.

The cysticerci identification was performed through the process of evagination when they were alive because they were submitted first to the $\mathrm{HCl}$ juice for 45 minutes $\left(37^{\circ} \mathrm{C}\right)$ and then to bile juice from 5 to 15 minutes. The evaginated cysticerci that presented four suckers in the scolex and a pseudo-strobila segment were considered Cysticercus bovis. The cheesy types, calcified ones and the ones that failed to desinvaginated were also considered Cysticercus bovis; however their identification was not precise.

\section{RESULTS AND DISCUSSION}

The total number of recovered cysticerci was 702 from all the animals. From the total $570(81.20 \%)$ cysticerci were alive and $132(18.80 \%)$ were degenerated. Table 1 presents the experimental infection protocol and necropsy results. The cysticerci found in the infected calves were anatomically distributed in: organs (heart, diaphragm, lungs, kidneys, liver and tongue) 104 $(14.81 \%)$ and skeleton muscles 598 (85.19\%) (Table 2). The anatomic distribution varied among the animals but the largest number of cysts was found in the anterior skeleton muscles (Table 3). 
The cysticerci identification was confirmed through the optical and electronic scanning microscopy. Scolex, neck and pseudo-strobila were visualized through the optical microscopy. In the scolex was possible to identify the four suckers to confirm the Cysticercus bovis. The adult bovine presented only two calcified cysticerci but it showed around 300 spots on the liver surface and in its innards. The presence of spots indicated a starting infection process but the liver barrier was efficient to halt the normal development of cysticerci. The scolex structures were measured and the mean values are in Table 4.

Table 1 - Alive and degenerated cysticerci recovered from calves experimentally infected with Taenia saginata eggs.

\begin{tabular}{cccccc} 
No. of & Day & \multicolumn{4}{c}{ Recovered cysticerci } \\
\cline { 3 - 6 } animal & of infection & alive & degene-rated & total & Rate $(\mathrm{r}) \%$ \\
\hline 01 & 111 & 568 & 17 & 585 & 2.9 \\
03 & 90 & 0 & 104 & 104 & 0.52 \\
04 & 90 & 02 & 09 & 11 & 0.05 \\
09 & 104 & 0 & 02 & 02 & 0.01 \\
\hline
\end{tabular}

(r) recuperation rate

Table 2 - Total number of recovered cysticerci by anatomic region of calves experimentally infected with Taenia saginata eggs.

\begin{tabular}{cc}
\hline Anatomic Region & Total (\%) \\
\hline Heart & $49(6.98 \%)$ \\
Diaphragm & $18(2.56 \%)$ \\
Lung & $15(2.14 \%)$ \\
Liver & $12(1.71 \%)$ \\
Tongue & $07(1.00 \%)$ \\
Kidney & $03(0.43 \%)$ \\
Anterior muscles & $323(46.00 \%)$ \\
Posterior muscles & $248(35.33 \%)$ \\
Head & $27(3.85 \%)$ \\
\hline
\end{tabular}

Table 3 - Cysticerci recovered by organ and by animal experimentally infected with Taenia saginata eggs.

\begin{tabular}{cccccccccc}
\hline $\begin{array}{c}\text { Animal } \\
\mathrm{n}^{\circ}\end{array}$ & \multicolumn{1}{c}{ Heart } & Liver & Lung & Tongue & Kidney & Diaphragm & Anterior & Posterior & Head \\
\hline 01 & 25 & 8 & 15 & 6 & 2 & 15 & 284 & 204 & 26 \\
03 & 22 & 3 & - & 1 & - & 3 & 35 & 39 & 01 \\
04 & 1 & 1 & - & - & - & - & 4 & 5 & - \\
09 & 1 & - & - & - & 1 & - & - & - & - \\
\hline
\end{tabular}

Table 4 - Measures of evaginated cysticerci correctly identified as Cysticercus bovis obtained from animals experimentally infected with Taenia saginata eggs.

\begin{tabular}{cccccc}
\hline $\begin{array}{c}\text { Animal } \\
\mathrm{n}^{\circ}\end{array}$ & $\begin{array}{l}\mathrm{N}^{\circ} \text { of evaginated } \\
\text { and measured } \\
\text { cysticerci }\end{array}$ & Width $(\mu \mathrm{m})$ & Length $(\mu \mathrm{m})$ & $\begin{array}{c}\text { Suckers } \\
\text { Diameter }(\mu \mathrm{m})\end{array}$ & $\begin{array}{c}\text { Ventosiform } \\
\text { depression } \\
\text { Diameter }(\mu \mathrm{m})\end{array}$ \\
\hline 01 & 16 & 845.62 & 893.28 & 305.28 & 246.76 \\
04 & 02 & 781.05 & 836.40 & 312.11 & 107.63 \\
\hline
\end{tabular}


The diagnosis of bovine cysticercosis infection with Cysticercus bovis is routinely determined by visual inspection through specific slices in the carcasses in the slaughterhouses. It presents a low sensitivity when the infection level is initial (Murrel et al.,1986; Kyvsgaard et al., 1989). Only two out of four infected animals in this experiment were identified as infected animals through this routine inspection. After the inspection by slicing, 702 cysticerci were recovered, 570 cysticerci were alive (81.2\%) and $132(18.8 \%)$ were degenerated. The mean recovery rate in relation to the number of ingested eggs was $0.88 \%$.

The number of cysticerci found in the normally inspected tissues by the sanitary services were 7 $(1.0 \%)$ in the tongue, $18(2.56 \%)$ in the diaphragm, $25(3.56 \%)$ in the mastication muscles, $49(6.98 \%)$ in the heart, making the total of $99(14.1 \%)$. The remaining $85.9 \%$ of cysts were found in the skeleton muscles and other organs that were not examined in the routine tests of the sanitary inspection service. These remaining cysts were 2 $(0.28 \%)$ in hioideo muscles, $3(0.43 \%)$ in the kidneys, $12(1.71 \%)$ in the liver, $15(2.14 \%)$ in the lungs, 323 (46\%) anterior muscles, 248 (35.33\%) posterior muscles. These results are very similar to those found by Fan et al., (1992) in a work that 303 (3\%) cysticerci were recovered from 10,000 inoculated eggs. These authors reported that the recovered cysts were $15.66 \%$ from the routinely examined tissues and $84.34 \%$ from the skeleton muscles that were not examined. An experimental infection conducted with a 4 months old calf showed that cysticerci were in the heart $(16.67 \%)$ and in the skeleton muscles $(83.33 \%$ ) (Fan et al., 1988).

Walter and Koske (1980) found that only 23 $(38.3 \%)$ out of 60 cysticerci infected bovines were detected through a regular inspection and the remaining $37(61.7 \%)$ were identified as infected only by the slicing technique. According to routine inspection few selected tissues are only partially investigated, therefore fewer slices are done. A more careful examination conducted in these tissues could result in great economic loss. In routine inspection only a partial slicing up to $50 \%$ of the inspected tissues would make possible to find only $7.05 \%$ of the present cysticerci. Therefore for each cysticerci found in the routinely inspected tissues there are 6.1 undetected ones distributed in the remaining organs and muscles. Moreover, some cysts can be in the carcass even if the inspected tissues look like free of them. The limitations of the bovine cysticercosis are evident mainly if the infection is in a low level. Santos (1993) observed that $96.7 \%(4,222)$ of 4,366 infected bovines presented only one cysticercus. However, other cysticerci might be present in the skeleton muscles.

According to our results, $14.1 \%$ of cysticerci were found in the routinely inspected tissue. Probably due to this limitation in the inspection the most efficient sanitary system could not interrupt the parasite disease cycle. Thus in order to prevent the continuous parasite cycle, it would be necessary to improve the inspection efficiency. This could be achieved by extending the examinations to some other tissues, therefore it would be necessary to include some less important muscles simultaneously with an increase in the number and the depth of the incisions. Moreover, the inspectors awareness of the correct identification and treatment of infected carcasses to prevent the development of new Taenia infections.

The data showed that a high percentage of the infected carcasses remained undetected. $85.9 \%$ of cysticerci found by the slicing technique would have not been detected in a routinely conducted inspection. It would be necessary to conduct a slicing technique in all organs and the skeleton muscles each five $\mathrm{mm}$.

The cheesy and calcified cysts found in the bovines were not necessarily Cysticercus bovis especially when they were small. In the present work all the found cysts were considered as Taenia saginata. Two animals had degenerated cysts and one presented only two cysticerci, however, presented around 300 white spots in liver. The presence of these spots indicated that an initial infection process took place but it was prevented by imunological barrier that halted the normal cysticerci development. At the infection time this bovine was 19 months old. The age at the infection time seems to be important to prevent the cysticerci development (Soulsby, 1963).

\section{CONCLUSIONS}

1. In the experimental infection metacestode Cysticercus bovis were found distributed in all bovine muscles. The localization of cysticerci had no preference for any tissue inspected by the experimental service. They were present in the tongue, heart, diaphragm, and chewing muscles. 
2. The adult bovines were more resistant to Taenia saginata egg infection showing lesser number of cysticerci and a higher number of calcified cysts.

3. The inspection routine data does not allow to estimate the incidence of bovine cysticercosis.

\section{RESUMO}

Foi avaliada a taxa de recuperação e localização de cisticercos em bovinos experimentalmente infectados com ovos de Taenia saginata. Três bezerros de 6,5 meses e um adulto com 19 meses de idade foram infectados, por via oral, com $2 \mathrm{x}$ $10^{4}$ ovos de Taenia saginata. Um quinto bezerro serviu como testemunha. Após 90 dias da infecção, os animais foram abatidos. Fez-se inspeção, de todos os animais, por fatiamento de órgãos e musculatura esquelética, com intervalo entre os cortes de, no máximo, cinco milímetros. Dos quatros bezerros desafiados foram recuperados 702 cisticercos sendo $570(81,20 \%)$ vivos e $132(18,80 \%)$ degenerados. A taxa de recuperação foi de $0,01 \%$ a $1,43 \%$ com média de $0,88 \%$. Os 702 cistos encontrados apresentaram a seguinte distribuição anatômica: músculos hióideos $02(0,28 \%)$, rins $03(0,43 \%)$, língua 07 (1,00\%), fígado $12(1,71 \%)$, pulmões $15(2,14 \%)$, diafragma $18(2,56 \%)$, músculos da mastigação 25 $(3,56 \%)$, coração $49 \quad(6,98 \%)$, musculatura dianteira $323(46,00 \%)$ e musculatura traseira 248 $(35,33 \%)$. Na infecção experimental os cistos encontraram-se distribuídos por toda a musculatura dos animais, não mostrando predileção pelos tecidos normalmente pesquisados pelo serviço de inspeção (língua, coração, diafragma, músculos mastigatórios). Os dados da inspeção de rotina pode não estimar a real incidência da cisticercose bovina. Os bovinos adultos são mais resistentes a infecção por ovos de Taenia saginata, apresentando menor número de cisticercos e com maior número de cistos calcificados.

\section{REFERENCES}

Encontro do Cone Sul e Seminário Latino Americano sobre Teníase e Cisticercose (1994), Anais... Curitiba : Secretaria de Saúde do Estado do Paraná. pp. 38-44.

Fan, P. C. (1988), Taiwan Taenia and taeniasis. Parasitology Today, 4, 86-88.
Fan, P. C.; Lin, C. Y. and Wu, C. C. (1989), Experimental studies of Korea Taenia (Cheju strain) infection in domestic animals. Annals of Tropical Medicine and Parasitology, 83 : (4), 395-403.

Fan, P. C.; Chung, W. C.; Lin, C. Y. and Pawlowski, Z. S. (1992), Experimental infection with Taenia saginata (Poland strain) in Taiwanese pigs. Journal of Helminthology, 66, 198-204.

Guidelines for Surveilance Prevention and Control of Taeniasis Cysticercosis (1983), Genève : World Health Organization (WHO). pp. 68-126.

Hayunga, E. G.; Wong, M. M.; Sumner, M. P. and Isenstein, R. S. (1991), Evaluation of a 'dipstick' immunoassay to detect cysticercosis in experimentally infected cattle. Veterinary Parasitology, 3813-22.

Kyvsgaard, N. C.; Ilsoe, B.; Henriksen, S. A. and Nansen, P. (1989), Distribution of Taenia saginata cists in carcasses of experimentally infected calves and its dignificance for routine meat inspection. Reserch Veterinary Science, 49, 29-30.

Kyvsgaard, N. C.; Ilsoe, B.; Henriksen, S. A.; Feld, N. C. and Nansen, P. (1991), Evaluation of an enzymelinked immunosorbent assay (ELISA) for detection of Taenia saginata cysticercosis in cattle. Acta Veterinaria, Scandinavia, 32, 233-241.

Murrel, K. D.; Fayer, R.and Dubey, J. P. (1986), Parasitic organisms. Advances in Meat Reserch, 2, 311-376.

Santos, I. F. (1993), Diagnóstico da cisticercose bovina em matadouros. Higiene Alimentar, 7 : (25), 26-34.

Smith, H. J.; Snowon, K. E. and Finlay, R. C. (1991), Serological diagnosis of cysticercosis by an enzymelinked immunosorbent assay in experimentally infected cattle. Canadian Journal of Veterinary Research, 55 : (3), 274-276.

Soulsby, E. J. L. (1963), Imunological unresponsiveness to helminth infections in animals. In: $17^{\circ}$ International Veterinary Congress. Proceedings... Hannover. pp.761-767.

Walter, M. and Koske, J. K. (1980), Taenia saginata cysticercosis: a comparison of routine meat inspection and carcass dissection results. Veterinary Record, 106, 401-402.
Received: April 23, 2001; Revised: July 27, 2001; Accepted: November 11, 2001. 